\title{
Elżbieta Dostosowanie dochodów do zadań Malinowska-Misiąg* samorządu terytorialnego w Polsce. Wojciech Misiąg** Praktyka i rekomendacje
}

Adjusting revenues to local government tasks in Poland. Practice and recommendations

The article deals with the problem of adjusting the revenues of Polish local government units (LGUs) to their tasks. The problem was analysed both from the point of view of the possibility of increasing LGU revenues and designing an effective system of fiscal equalization. The authors discussed the external factors which limit the possibilities of introducing such a desirable system. Next, based on the presented analysis, they drew conclusions regarding the necessary revision of the existing scheme. The article concludes with specific recommendations for a new system of financing LGUs, assuming, in particular, far-reaching changes in the algorithms for determining and dividing general subsidies, as well as a fundamental reduction in the scope of the so-called commissioned tasks.

\begin{tabular}{|c|c|}
\hline DOI & https://doi.org/10.31268/StudiaBAS.2021.03 \\
\hline Słowa kluczowe & $\begin{array}{l}\text { samorząd terytorialny w Polsce, dochody własne, wyrównywanie } \\
\text { fiskalne, subwencja ogólna, dotacje celowe }\end{array}$ \\
\hline Keywords & $\begin{array}{l}\text { local government in Poland, own revenues, fiscal equalization, general } \\
\text { subsidies, targeted subsidies }\end{array}$ \\
\hline \multirow[t]{2}{*}{0 autorach } & $\begin{array}{l}\text { * doktor nauk ekonomicznych, adiunkt w Instytucie Finansów } \\
\text { (Katedra Systemu Finansowego) Szkoły Głównej Handlowej } \\
\text { w Warszawie • } ₫ \text { emisia@sgh.waw.pl • } \\
\text { ORCID 0000-0001-8710-781X }\end{array}$ \\
\hline & $\begin{array}{l}\text { ** doktor nauk ekonomicznych, profesor Wyższej Szkoły Informatyki } \\
\text { i Zarządzania w Rzeszowie, dyrektor generalny Instytutu Badań } \\
\text { i Analiz Finansowych WSIiZ • } ₫ \text { wmisiag@wsiz.edu.pl · } \\
\text { ORCID 0000-0002-1751-285X }\end{array}$ \\
\hline
\end{tabular}

\section{Wstęp}

Konstrukcja systemu dochodowego jednostek samorządu terytorialnego (JST) należy do najważniejszych, ale i najtrudniejszych zagadnień prawa finansowego. O wadze tego problemu świadczy zarówno jego wymiar finansowy, jak i znaczenie, jakie system ten ma dla sprawnego i efektywnego funkcjonowania jednostek samorządu terytorialnego.

Źródłem istotnych trudności przy projektowaniu systemu finansów samorządowych jest również to, że na obraz idealnego systemu składa się wiele - często niełatwych do pogodzenia kryteriów i postulatów, a jednocześnie podlega on różnorodnym ograniczeniom wymuszającym odejście od modelowego kształtu tego systemu. Należy przy tym zauważyć, że część tych ograniczeń nie jest spowodowana przyczynami naturalnymi (wynikającymi np. z ukształtowania powierzchni kraju, różnic klimatycznych, zróżnicowanej przydatności dla rolnictwa i turystyki, czy też wymagań ochrony środowiska), lecz wynika z cech ustrojowych państwa i politycznie warunkowanych możliwości dostosowania prawa do wymogów sprawnie działającego samorządu terytorialnego. Tak jest np. w przypadku systemu opodatkowania rolnictwa, funkcjonowania 
Karty Nauczyciela, zakresu i warunków przyznawania świadczeń z ubezpieczeń społecznych i innych świadczeń socjalnych.

Punktem wyjścia do konstrukcji systemu finansów samorządowych jest zakres zadań publicznych powierzonych JST. System powinien być tak zaprojektowany, by przydzielone JST zadania publiczne mogły być sfinansowane w stopniu zapewniającym zachowanie ustalonych standardów jakościowych. Podział zadań publicznych pomiędzy centralne organy władzy publicznej i samorząd terytorialny powinien być zgodny z ogólnymi zasadami ustrojowymi obowiązującymi w państwie. Odejście od tych zasad może w istotny sposób utrudnić zaprojektowanie dobrego systemu finansów samorządowych. Jako przykłady można wskazać pozbawienie JST realnego wpływu na organizację i finansowanie podstawowej opieki zdrowotnej, obciążenie ich obowiązkiem wykonywania wielu zadań administracji rządowej, czy wreszcie przeniesienie na JST ryzyka związanego ze zmianami w systemie wynagradzania nauczycieli. Z tego względu zasady podporządkowania systemu finansowania JST obecnemu podziałowi zadań pomiędzy organy władzy państwowej i JST nie powinniśmy traktować jako bezwzględnie obowiązującej. Konstrukcja systemu dochodów JST wymaga:

- wyceny globalnych kosztów zadań samorządowych;

- podziału dostępnych rodzajów dochodów publicznych pomiędzy Skarb Państwa i JST, przy czym możliwe jest albo przypisanie w całości wpływów z jednego źródła dochodów władzom centralnym lub samorządowym, albo podział tych wpływów - w ustalonych proporcjach między różne szczeble władzy publicznej;

- oceny, czy dochody należne poszczególnym JST są wystarczające do sfinansowania kosztów wykonania przypisanych tym jednostkom zadań publicznych, kalkulowanych z uwzględnieniem uzasadnionych różnic kosztów wykonania tych samych zadań w różnych JST;

- ustalenia zasad uzupełniającego zasilania tych JST, dla których przyznane im dochody własne są niewystarczające.

Przy określonym katalogu dochodów (JST nie mają możliwości wykreowania własnych tytułów dochodowych) i określonym zakresie zadań publicznych przypisanych różnym typom JST istnieje wiele możliwości podziału dochodów publicznych pomiędzy Skarb Państwa i samorząd terytorialny, chociaż nie wszystkie rodzaje dochodów publicznych mogą być brane pod uwagę jako źródła dochodów samorządowych - przeszkodą może być zarówno ewidentnie ogólnopolski charakter dochodów, jak i bardzo nierównomierny rozkład dochodów.

Opisane powyżej czynniki zmniejszające zakres możliwych do zaakceptowania podziałów dochodów pomiędzy Skarb Państwa i JST pozostawiają jednak nadal pewną przestrzeń wyboru. Za kryteria porównywania różnych wariantów wykazu dochodów samorządowych można przyjąć:

- stopień sfinansowania wydatków samorządowych dochodami własnymi;

- wrażliwość dochodów na procesy inflacyjne i inne czynniki powodujące wzrost kosztów wykonywania zadań samorządowych;

- możliwości oddziaływania JST na wielkość przyznanych im dochodów własnych;

- uwzględnienie w systemie dochodów stałych zasad dostosowujących poziom dochodów samorządowych do zmian zakresu ich zadań (w sensie zarówno jakościowym, jak i ilościowym) oraz do zmian legislacyjnych wpływających na rozmiary dochodów samorządowych; 
- stopień formalizacji zasad ustalania dochodów wyrównawczych, wyrażający się w dążeniu do maksymalnego ograniczenia arbitralnego oddziaływania administracji rządowej na wielkość środków przekazywanych JST.

Gdy przełożymy te kryteria na praktyczne decyzje, które trzeba podjąć przy projektowaniu systemu finansów JST, możemy stwierdzić, że:

- należy dążyć do przyznania JST możliwie szerokiego i zróżnicowanego zestawu dochodów własnych;

- jednostki samorządu terytorialnego powinny mieć istotny wpływ na wysokość przypisanych im dochodów';

- system dochodów samorządowych powinien zapewniać stosowny do rozmiarów zadań udział JST w podziale fiskalnych efektów wzrostu gospodarczego;

- gwarancje przyznane JST powinny oznaczać konieczność zapewnienia tym jednostkom rekompensaty finansowej we wszystkich przypadkach zmian legislacyjnych oddziałujących niekorzystnie na stan równowagi finansowej sektora samorządowego.

Przy konstruowaniu systemu dochodów samorządowych nie można zapominać o konieczności zapewnienia stabilnego finansowania również zadań o charakterze ogólnokrajowym, wykonywanych przez instytucje sektora rządowego (centralnego). Może to prowadzić do konieczności ograniczenia zakresu zadań własnych na rzecz zwiększenia transferów z budżetu państwa. Wynika to stąd, że w odróżnieniu od innych rodzajów dochodów samorządowych transfery z budżetu mogą być kształtowane - przez właściwe zaprojektowanie algorytmów obliczania wielkości tych transferów - dość elastycznie. Dzięki ograniczeniu zakresu dochodów własnych i zwiększeniu udziału transferów z budżetu państwa można uniknąć „przefinansowania” JST wynikającego z konieczności zapewnienia wystarczających środków wszystkim jednostkom. Istnieje obecnie w Polsce grupa gmin, w których nawet przyznanie im - jako dochodów własnych - wszystkich dochodów podatkowych poza podatkiem od towarów i usług oraz akcyzą od wszystkich podatników mieszkających na terenie tych gmin lub mających tam swoją siedzibę nie pokrywałoby wszystkich niezbędnych wydatków tych gmin.

\section{Stabilność a elastyczność systemu dochodów JST}

Od systemu dochodów samorządowych wymaga się spełnienia dwóch, dość trudnych do jednoczesnego zrealizowania, postulatów, a mianowicie stabilności i elastyczności. Elastyczność

1 Szerzej na temat samodzielności dochodowejJST np.: J. Glumińska-Pawlic, Samodzielność finansowa jednostek samorzq̨u terytorialnego w Polsce. Studium finansowoprawne, Wydawnictwo Uniwersytetu Śląskiego, Katowice 2003; K. Surówka, Samodzielność finansowa samorządu terytorialnego w Polsce, Polskie Wydawnictwo Ekonomiczne, Warszawa 2013; M. Poniatowicz, Determinanty autonomii dochodowej samorzadu terytorialnego w Polsce, „Prace Naukowe Uniwersytetu Ekonomicznego we Wrocławiu” 2015, nr 404 [Finanse samorzqdu terytorialnego, red. L. Patrzałek, H. Kociemska], https://doi.org/10.15611/pn.2015.404.17; K. Brzozowska, M. Kogut-Jaworska, Władztwo podatkowe w ocenie samodzielności dochodowej gmin w Polsce, „Annales Universitatis Mariae Curie-Skłodowska. Sectio H. Oeconomia" 2016, t. 50, nr 1, https://doi.org/10.17951/h.2016.50.1.327; D. Wyszkowska, Samodzielność finansowa jako determinanta potencjału inwestycyjnego jednostek samorzadu terytorialnego. Studium empiryczne gmin w Polsce, Wydawnictwo Uniwersytetu w Białymstoku, Białystok 2018. 
wyraża się w takiej konstrukcji systemu, w której możliwe jest jego płynne dostosowanie do zmieniających się warunków, przy czym należy przez to rozumieć zarówno zmiany zakresu zadań i zmiany kosztów wykonania tych zadań spowodowane decyzjami zapadającymi niezależnie od samorządu terytorialnego (np. przez ustawowe podwyższenie standardów wykonania zadania), jak i zmiany legislacyjne mające wpływ na rozmiary dochodów JST.

Rozwiązaniem kolizji postulatów stabilności i elastyczności systemu dochodowego powinno być ustanowienie jasnych reguł określających przypadki, w których niezbędne jest dokonanie zmian rekompensujących JST niekorzystne dla nich skutki działań legislacyjnych. Wydaje się, że punktem wyjścia do konstrukcji tych reguł powinno być przyjęcie - po niezbędnych korektach obecnego systemu finansowania JST - „opcji zerowej”, czyli założenia, że w momencie wejścia w życie nowego systemu będą spełnione wszystkie opisane powyżej warunki zapewniające JST możliwość wykonania nałożonych na nie zadań. Oznaczałoby to, że wszelkie zmiany regulacji odnoszących się do dochodów i wydatków JST wprowadzane po wejściu w życie nowego systemu finansowego powinny być analizowane pod kątem ich wpływu na finanse samorządowe i powinny zawierać rozwiązania dostosowujące finanse samorządu do nowego stanu prawnego. Funkcjonowanie takiego mechanizmu wymaga oczywiście istnienia efektywnych gwarancji finansowych dla JST.

W sporach pomiędzy administracją rządową a samorządem terytorialnym dotyczących braku finansowej rekompensaty przy wprowadzaniu nowych rozwiązań prawnych naruszających finanse samorządowe często pojawia się argument o możliwości pokrycia finansowych skutków nowych regulacji dzięki stałemu wzrostowi dochodów samorządowych. Argument taki nie jest z gruntu niesłuszny, jednak odwołaniu się do możliwości pokrycia dodatkowych kosztów (lub zrekompensowania utraconych dochodów) „naturalnym” wzrostem dochodów samorządowych wynikającym z procesów inflacyjnych i wzrostu gospodarczego powinny towarzyszyć szczegółowe wyliczenia porównujące efekty wzrostu dochodów samorządowych z negatywnymi dla JST skutkami nowych rozwiązań prawnych. Niestety, takie wyliczenia nie są na ogół sporządzane.

\section{Równy dostęp do usług a samodzielność JST}

Istotnym problemem do rozwiązania przy konstrukcji systemu dochodów samorządowych jest konieczność pogodzenia - w takim stopniu, w jakim jest to możliwe - zasady zapewnienia wszystkim obywatelom równego dostępu do odpowiednich jakościowo usług publicznych świadczonych przez JST z samodzielnością samorządu terytorialnego, wyrażającą się w konstytucyjnej zasadzie, zgodnie z którą „Przysługującą mu w ramach ustaw istotną część zadań publicznych samorząd wykonuje w imieniu własnym i na własną odpowiedzialność" (art. 16 ust. 2 zd. 2 Konstytucji RP²).

Sposób, w jaki w konkretnej JST wykonywane są zadania publiczne, nie zależy wyłącznie od tego, jakimi środkami jednostka ta dysponuje, ani nawet od tego, w jakim stopniu środki te są,

2 Konstytucja Rzeczypospolitej Polskiej z dnia 2 kwietnia 1997 r. (Dz.U. nr 78, poz. 483, ze zm.; dalej: Konstytucja $\mathrm{RP})$. 
patrząc obiektywnie, wystarczające do poprawnego wykonania zadań samorządowych. Równie istotne jest bowiem to, czy administracja samorządowa potrafi efektywnie gospodarować dostępnymi środkami oraz czy decyzje alokacyjne podejmowane przez organy wykonawcze i stanowiące danej JST są zgodne z preferencjami i oczekiwaniami mieszkańców. Musimy więc przyjąć do wiadomości, że możliwa jest - i praktyka funkcjonowania samorządu to potwierdza - sytuacja, w której jakość usług świadczonych przez administrację samorządową będzie niezadowalająca mimo posiadania przez JST wystarczających środków finansowych.

Trudno wymagać, by taki stan rzeczy miał mieć konsekwencje w postaci obligatoryjnego zwiększenia puli środków kierowanych do takiej jednostki. Skoro samorząd terytorialny wykonuje zadania publiczne służące społeczności lokalnej lub regionalnej „na własną odpowiedzialność", to logiczne jest uznanie, że odpowiedzialność ta ciąży nie tylko na organach JST, ale że ponoszą ją wszyscy członkowie społeczności, mający (zwłaszcza w gminach, wykonujących największą część zadań samorządowych) decydujący wpływ na skład tych organów. Prowadzi to do stwierdzenia, że postulat zapewnienia wszystkim obywatelom, niezależnie od ich miejsca zamieszkania, równego dostępu do właściwych jakościowo usług publicznych znajdzie w systemie dochodów samorządowych właściwe odzwierciedlenie, gdy będą spełnione trzy podstawowe warunki:

- środki publiczne znajdujące się w dyspozycji każdej JST będą wystarczające, by przy założeniu przeciętnej w skali kraju efektywności wykonywania zadań publicznych zrealizować i sfinansować przypisane jednostce zadania publiczne;

- przy kalkulacji środków niezbędnych danej JST do wykonania nałożonych na nią zadań publicznych będą uwzględniane specyficzne dla tej jednostki czynniki powodujące konieczność ponoszenia ponadprzeciętnych wydatków na niektóre zadania;

- niezależne od JST zmiany kosztów wykonywania zadań samorządowych będą znajdowały szybkie odzwierciedlenie w zmianach systemu dochodów.

\section{Ograniczenia możliwości realizacji postulatów}

W realnych warunkach zaprojektowanie „idealnego” - rozumianego jako spełniający wszystkie opisane powyżej postulaty - systemu finansów samorządowych nie jest możliwe ze względu na występujące w praktyce ograniczenia, do których należy zaliczyć w szczególności:

- istniejący system dochodów publicznych i przyjmowane a priori założenie o niedopuszczalności kreowania dodatkowych obciążeń fiskalnych;

- zróżnicowanie potencjału dochodowego poszczególnych JST, wynikające zarówno z warunków naturalnych, istniejącej infrastruktury, jak i z ukształtowanego modelu działalności gospodarczej dominującej w poszczególnych JST;

- obiektywnie uzasadnione zróżnicowanie kosztów wykonywania zadań samorządowych, mające źródło np. w strukturze demograficznej mieszkańców czy w poziomie ich zatrudnienia i dochodów;

- schemat podziału administracyjnego państwa;

- istnienie norm prawnych uznawanych za "nienaruszalne” z przyczyn politycznych; 
- sytuację finansową sektora finansów publicznych i strukturalne niedostosowanie zakresu zadań i wymaganych standardów wykonania zadań publicznych do potencjału finansowego sektora finansów publicznych i jego zadłużenia.

Należy podkreślić, że chociaż tylko część wskazanych wyżej ograniczeń ma charakter bezwzględny, często ograniczenia, których usunięcie wydaje się formalnie proste, mają co najmniej taką samą siłę jak ograniczenia naturalne.

\section{Polski system dochodów JST}

Prawne ramy ogólnej koncepcji systemu dochodów samorządowych w Polsce tworzą przepisy:

- art. 167 ust. 1-3 Konstytucji RP: „1. Jednostkom samorządu terytorialnego zapewnia się udział w dochodach publicznych odpowiednio do przypadających im zadań. 2. Dochodami jednostek samorządu terytorialnego są ich dochody własne oraz subwencje ogólne i dotacje celowe z budżetu państwa. 3. Źródła dochodów jednostek samorządu terytorialnego są określone w ustawie";

- art. 168 Konstytucji RP: „Jednostki samorządu terytorialnego mają prawo ustalania wysokości podatków i opłat lokalnych w zakresie określonym w ustawie";

- art. 217 Konstytucji RP: „Nakładanie podatków, innych danin publicznych [...] następuje w drodze ustawy" - co wyklucza możliwość samodzielnego ustanawiania przez JST dochodów o charakterze publicznoprawnym;

- ustawy o gospodarce komunalnej ${ }^{3}$, nakładające ograniczenia na prowadzenie przez JST działalności gospodarczej wykraczającej poza zadania o charakterze użyteczności publicznej. Zamknięty katalog dochodów JST z art. 167 Konstytucji RP powoduje pewne trudności klasyfikacyjne, gdyż problematyczne jest zaliczenie do dochodów własnych zarówno udziałów we wpływach z podatków dochodowych (z podatku dochodowego od osób fizycznych - PIT i podatku dochodowego od osób prawnych - CIT) ${ }^{4}$, jak i np. dotacji z państwowych funduszy celowych oraz dotacji udzielonych przez państwowe lub samorządowe osoby prawne.

Bardziej szczegółowe zasady systemu finansowego JST zostały ustalone w ustawie z dnia 13 listopada 2003 r. o dochodach jednostek samorządu terytorialnego ${ }^{5}$, nowelizowanej już kilkadziesiąt razy. W ustawie tej określono w szczególności:

- podział dochodów podatkowych pomiędzy gminy i Skarb Państwa, w tym sposób podziału wpływów z podatków dochodowych pomiędzy Skarb Państwa, gminy, powiaty i województwa, przy czym powiatom i województwom przyznano wyłącznie udziały we wpływach z podatków dochodowych ${ }^{6}$;

3 Ustawa z dnia 20 grudnia 1996 r. o gospodarce komunalnej (Dz.U. 2021, poz. 679).

4 Szerzej np.: K. Wójtowicz, Udziały samorządów w podatkach państwowych - własne czy obce źródło dochodów JST? Dylematy teorii a praktyka budżetowa wybranych państw, „Prace Naukowe Uniwersytetu Ekonomicznego we Wrocławiu" 2013, nr 306.

5 Dz.U. 2021, poz. 38; dalej: ustawa o dochodach JST.

6 W rozumieniu ustawy o dochodach JST udziały we wpływach w podatkach dochodowych są traktowane jako dochody własne JST. 
- ogólnie sformułowany wykaz innych dochodów własnych;

- zasady ustalania subwencji ogólnej dla JST;

- ogólne zasady ustalania i przekazywania dotacji dla JST.

Wysokość subwencji ogólnej należnej każdej jednostce jest obliczana jako suma:

- części wyrównawczej, w ramach której wyróżnia się kwotę podstawową, zależną od dochodów jednostki, oraz kwotę uzupełniającą, wyliczaną na podstawie wskaźników określających pośrednio koszty wybranych zadań JST;

- części oświatowej, stanowiącej standardowe finansowanie wydatków JST na prowadzenie szkół i innych placówek oświatowych, przy czym dla większości JST należne wielkości nie pokrywają pełnych kosztów finansowania zadań edukacyjnych? ${ }^{7}$.

W łącznej kwocie subwencji ogólnej wyodrębnia się ponadto rezerwę subwencji oraz część równoważącą (dla gmin i powiatów) i część regionalną (dla województw). Źródłem finansowania tych części subwencji są wpłaty do budżetu państwa od JST charakteryzujących się najwyższymi dochodami na jednego mieszkańca (tzw. janosikowe).

W 2019 r. zasadniczą część (ok. 74,7\%) subwencji ogólnej dla wszystkich JST stanowiła część oświatowa, na część wyrównawczą przypadało ok. 19,9\% subwencji, a na części równoważącą i regionalną - 4,4\% łącznej kwoty subwencji. Jak widać, tylko stosunkowo mała część subwencji może być traktowana jako instrument niwelowania dysproporcji dochodowych między JST .

Drugą grupę dochodów samorządowych stanowią dotacje z budżetu państwa, zapewniające JST w ostatnich latach prawie 30\% ich dochodów. Największa część dotacji trafia do JST w formie dotacji na zadania zlecone z zakresu administracji rządowej, w tym na świadczenia z programu Rodzina 500+. Tylko nieco ponad jedną trzecią ogólnej kwoty dotacji stanowią dotacje do zadań własnych, wśród których dominują dotacje finansowane środkami zagranicznymi. Od lat dziewięćdziesiątych ubiegłego wieku trwają spory o należną JST wysokość dotacji na zadania zlecone i nie wydaje się, by można było znaleźć rozwiązanie bez zasadniczego zmniejszenia zakresu zadań zleconych ${ }^{9}$.

7 Por. np. J. Szołno-Koguc, Subwencja ogólna jako instrument wsparcia transferowego samorzq̨du gminnego, „Prace Naukowe Uniwersytetu Ekonomicznego we Wrocławiu” 2017, nr 485 [Relacje fiskalne państwo - samorzqd terytorialny, red. L. Patrzałek, H. Kociemska], http://dx.doi.org/10.15611/pn.2017.485.37.

80 mankamentach subwencji ogólnej jako instrumentu systemu korekcyjno-wyrównawczego szerzej: L. Patrzałek, Subwencja ogólna jako instrument korekcyjno-wyrównawczy w systemie finansów samorzqdu terytorialnego, „Prace Naukowe Uniwersytetu Ekonomicznego we Wrocławiu” 2015, nr 404 [Finanse samorzqdu terytorialnego, red. L. Patrzałek, H. Kociemska], https://doi.org/10.15611/pn.2015.404.16. Obszerną analizę na temat systemu wyrównywania przedstawiły m.in.: A. Sekuła, System subwencjonowania jednostek samorzqdu terytorialnego w Polsce: dysfunkcje i pożq̨dane kierunki racjonalizacji, Wydawnictwo Politechniki Gdańskiej, Gdańsk 2016 oraz S. Kańduła, Mechanizmy wyrównywania fiskalnego. Studium empiryczne gmin w Polsce w latach 2004-2014, Wydawnictwo Uniwersytetu Ekonomicznego w Poznaniu, Poznań 2017.

9 Szerzej np.: M. Dylewski, The Financing of Public Tasks Delegated to Local Governments - An Unresolved Systemic Problem, „Zeszyty Naukowe Wyższej Szkoły Bankowej w Poznaniu” 2016, t. 70, nr 5; E. Malinowska-Misiąg, Finansowanie zadań zlecanych jednostkom samorzqdu terytorialnego , „Studia BAS” 2017, nr 4(52) [Finansowanie zadań publicznych w Polsce, red. P. Russel]. 
Strukturę dochodów w poszczególnych grupach JST w 2019 r. przedstawiono na wykresie 1. Dla ułatwienia porównania dochodów miast na prawach powiatu (MPP) z dochodami innych gmin na wykresie zaznaczono czerwonymi segmentami słupków odpowiadających gminom dochody przypadające na jednego mieszkańca powiatów. Umożliwia to porównanie dochodów miast na prawach powiatu z dochodami innych gmin. Jak widać, nawet w takim ujęciu średnie dochody w miastach na prawach powiatu są wyraźnie wyższe niż dochody w innych gminach.

Wykres 1. Dochody gmin według rodzajów w 2019 r. (w zł na mieszkańca)

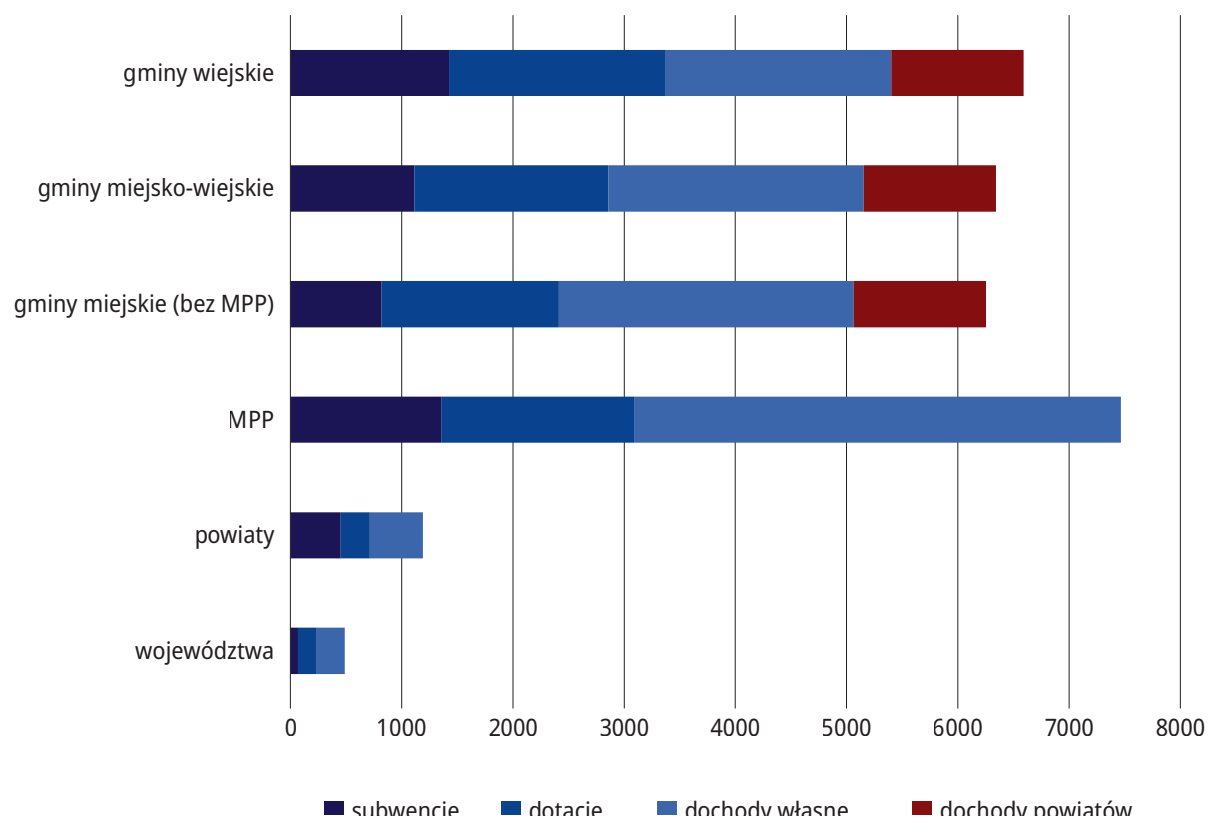

Źródło: obliczenia własne na podstawie: Rada Ministrów, Sprawozdanie z wykonania budżetu państwa za okres od 1 stycznia do 31 grudnia 2019 r. Informacja o wykonaniu budżetów jednostek samorzq̨du terytorialnego, Warszawa 2020.

Szczegółowy podział dochodów zaliczanych do trzech podstawowych kategorii dochodów JST w 2019 r. przedstawia tabela 1. Dane tam zawarte wskazują, że tylko stosunkowo niewielki odsetek transferów kierowanych do JST z innych instytucji publicznych może być traktowany jako instrumenty wyrównywania dysproporcji dochodowych - instrumentami tymi nie są ani część oświatowa subwencji ogólnej, ani dotacje na zadania zlecone, ani znacząca większość dotacji udzielanych ze środków zagranicznych. Konstrukcja części oświatowej subwencji ogólnej przewiduje dodatkowe środki dla JST prowadzących szkoły w miejscowościach liczących mniej niż 5 tys. mieszkańców. Środki te są jednak zbyt niskie, by mogły w istotny sposób przyczynić się do poprawy poziomu nauczania w małych miejscowościach. Dane dotyczące struktury dochodów podatkowych pokazują też, że wpływy z podatków lokalnych innych niż podatek od nieruchomości stanowią niewielki udział w dochodach gmin. 
Tabela 1. Struktura dochodów JST w 2019 r.

\begin{tabular}{|c|c|c|c|c|c|c|c|c|}
\hline \multirow{3}{*}{ Rodzaje dochodów } & \multirow[b]{2}{*}{$\begin{array}{c}\text { JST } \\
\text { ogółem }\end{array}$} & \multicolumn{5}{|c|}{ Gminy } & \multirow[b]{2}{*}{$\begin{array}{c}\text { Powia- } \\
\text { ty }\end{array}$} & \multirow[b]{2}{*}{$\begin{array}{c}\text { Woje- } \\
\text { wódz- } \\
\text { twa }\end{array}$} \\
\hline & & $\begin{array}{l}\text { Ogó- } \\
\text { tem }\end{array}$ & MPP & $\begin{array}{l}\text { Miej- } \\
\text { skie }\end{array}$ & $\begin{array}{l}\text { Miej- } \\
\text { sko- } \\
\text {-wiej- } \\
\text { skie }\end{array}$ & $\begin{array}{l}\text { Wiej- } \\
\text { skie }\end{array}$ & & \\
\hline & \multicolumn{8}{|c|}{ Dochody ogółem = 100} \\
\hline Dochody ogółem & 100,0 & 100,0 & 100,0 & 100,0 & 100,0 & 100,0 & 100,0 & 100,0 \\
\hline Subwencja ogólna & 22,2 & 20,8 & 18,2 & 16,2 & 21,6 & 26,4 & 37,9 & 13,7 \\
\hline Część oświatowa & 16,8 & 16,5 & 16,8 & 14,4 & 16,1 & 17,3 & 27,9 & 3,3 \\
\hline Pozostałe części subwencji & 5,3 & 4,3 & 1,5 & 1,8 & 5,5 & 9,1 & 10,0 & 10,4 \\
\hline Dotacje & 29,1 & 29,7 & 23,1 & 31,4 & 33,8 & 35,9 & 21,9 & 33,5 \\
\hline Na zadania zlecone & 19,1 & 21,6 & 15,6 & 23,0 & 25,8 & 27,0 & 9,7 & 3,9 \\
\hline Krajowe do zadań własnych & 3,6 & 3,2 & 2,4 & 3,8 & 3,6 & 3,7 & 7,0 & 3,5 \\
\hline Zagraniczne & 6,4 & 4,9 & 5,1 & 4,7 & 4,5 & 5,2 & 5,3 & 26,1 \\
\hline Dochody własne & 48,7 & 49,6 & 58,6 & 52,4 & 44,6 & 37,7 & 40,1 & 52,8 \\
\hline Udziały we wpływach z PIT & 20,2 & 21,0 & 26,5 & 21,7 & 17,5 & 14,7 & 20,4 & 9,6 \\
\hline Udziały we wpływach z CIT & 3,9 & 1,6 & 2,8 & 1,2 & 0,9 & 0,4 & 0,7 & 37,5 \\
\hline Podatek od nieruchomości & 8,4 & 10,2 & 9,6 & 12,5 & 11,6 & 8,8 & - & - \\
\hline Pozostałe podatki & 2,3 & 2,8 & 2,3 & 2,0 & 3,1 & 3,6 & - & - \\
\hline Pozostałe dochody własne & 13,9 & 14,0 & 17,4 & 15,0 & 11,5 & 10,2 & 19,0 & 5,7 \\
\hline
\end{tabular}

Źródło: obliczenia własne na podstawie: Rada Ministrów, op. cit.

Analiza wykresu 1 i tabeli 1 wskazuje, że - wbrew dość powszechnej opinii - średnie dochody przypadające na jednego mieszkańca gmin wiejskich są wyższe niż w gminach miejskich i miejsko-wiejskich. Ten dość zaskakujący wynik ma źródło w dużym zróżnicowaniu wewnętrznym gmin wiejskich - oprócz gmin typowo rolniczych, które faktycznie charakteryzują się niskimi dochodami na jednego mieszkańca, status gmin wiejskich mają również gminy o innym charakterze i znacznie większym potencjale dochodowym. Granica między gminami „biednymi” i „względnie bogatymi" przebiega więc nie pomiędzy gminami wiejskimi a gminami miejskimi i miejsko-wiejskimi, lecz pomiędzy gminami rolniczymi a gminami, w których dominuje działalność pozarolnicza.

Potwierdzenie tej tezy stanowią dane zawarte w tabeli 2 i na wykresie 2 . W tabeli 2 zestawiono dochody 15 gmin wiejskich o największych dochodach własnych na jednego mieszkańca. Żadna z tych gmin nie ma charakteru rolniczego - część z nich to miejscowości turystyczne, kilka jest położonych na terenach górniczych, kilka innych to gminy stanowiące bezpośrednie zaplecze dużych miast. Zwraca uwagę bardzo wysoki udział w dochodach własnych wpływów z podatku od nieruchomości - wyjątkiem jest gmina Ostrów zawdzięczająca swój potencjał dochodowy wielkiemu zakładowi składowania i utylizacji odpadów, obsługującemu znaczną część województwa podkarpackiego. 
Tabela 2. Gminy wiejskie z najwyższymi dochodami na mieszkańca w 2019 r.

\begin{tabular}{|c|c|c|c|c|c|c|c|}
\hline \multirow{4}{*}{ Gminy (województwo) } & \multirow[b]{3}{*}{ Ogółem } & \multicolumn{4}{|c|}{ Dochody własne } & \multirow{3}{*}{$\begin{array}{c}\text { Sub- } \\
\text { wencja } \\
\text { ogólna }\end{array}$} & \multirow[b]{3}{*}{ Dotacje } \\
\hline & & \multirow[b]{2}{*}{ Ogółem } & \multicolumn{3}{|c|}{ w tym: } & & \\
\hline & & & $\begin{array}{c}\text { udziały } \\
\text { w PIT } \\
\text { i CIT }\end{array}$ & $\begin{array}{l}\text { podatek } \\
\text { od nie- } \\
\text { rucho- } \\
\text { mości }\end{array}$ & $\begin{array}{c}\text { pozo- } \\
\text { stałe } \\
\text { podatki }\end{array}$ & & \\
\hline & \multicolumn{7}{|c|}{ zł } \\
\hline Kleszczów (łódzkie) & 45832 & 41372 & 3053 & 22584 & 258 & 2771 & 1689 \\
\hline Rewal (zachodniopomorskie) & 14072 & 11786 & 1259 & 4210 & 551 & 1177 & 1110 \\
\hline Rząśnia (łódzkie) & 12718 & 9999 & 757 & 4205 & 53 & 1071 & 1649 \\
\hline Kobierzyce (dolnośląskie) & 11516 & 8551 & 3017 & 3413 & 1055 & 1144 & 1820 \\
\hline $\begin{array}{l}\text { Ustronie Morskie } \\
\text { (zachodniopomorskie) }\end{array}$ & 10453 & 7922 & 922 & 2896 & 429 & 918 & 1614 \\
\hline Jerzmanowa (dolnośląskie) & 10279 & 7384 & 1697 & 2418 & 138 & 1051 & 1844 \\
\hline Mielnik (podlaskie) & 9266 & 7035 & 808 & 4864 & 261 & 697 & 1534 \\
\hline Grębocice (dolnośląskie) & 9798 & 6997 & 884 & 3705 & 193 & 1076 & 1725 \\
\hline $\begin{array}{l}\text { Tarnowo Podgórne } \\
\text { (wielkopolskie) }\end{array}$ & 9694 & 6256 & 3044 & 2201 & 293 & 1353 & 2086 \\
\hline Ostrów (podkarpackie) & 9738 & 6228 & 574 & 438 & 108 & 1465 & 2045 \\
\hline Suchy Las (wielkopolskie) & 9139 & 6212 & 2850 & 1976 & 749 & 1215 & 1713 \\
\hline Sulmierzyce (łódzkie) & 9510 & 6185 & 834 & 3828 & 101 & 941 & 2384 \\
\hline Szczerców (łódzkie) & 9087 & 6140 & 1161 & 2404 & 86 & 1381 & 1566 \\
\hline $\begin{array}{l}\text { Postomino } \\
\text { (zachodniopomorskie) }\end{array}$ & 10533 & 6089 & 748 & 3809 & 299 & 980 & 3464 \\
\hline Nadarzyn (mazowieckie) & 9760 & 6086 & 2832 & 1713 & 903 & 1436 & 2239 \\
\hline Średnia dla gmin wiejskich & 5402 & 2036 & 818 & 477 & 193 & 1426 & 1940 \\
\hline
\end{tabular}

Źródło: obliczenia własne na podstawie: Ministerstwo Finansów, Bazy danych po IV kwartałach 2019 r. - Dochody po IV kwartałach 2019 r., https://www.gov.pl/web/finanse/bazy-danych2 [dostęp: 28 kwietnia 2021 r.].

Na wykresie 2 przedstawiono rozkład dochodów własnych gmin wiejskich na jednego mieszkańca w 2019 r. zestawiony po uporządkowaniu gmin według malejących dochodów własnych na jednego mieszkańca, w podziale na 103 grupy, z których 102 liczyły po 15 gmin, ostatnia zaś grupa - 24 gminy o najniższych dochodach. Na wykresie zaznaczono też średnią wielkość dochodów własnych przypadających na jednego mieszkańca gmin wiejskich. Widoczna jest asymetria rozkładu - tylko ok. 30\% gmin wiejskich osiąga dochody własne przekraczające średnią dla całej grupy. 
Wykres 2. Dochody własne gmin wiejskich na mieszkańca w 2019 r. według grup centylowych

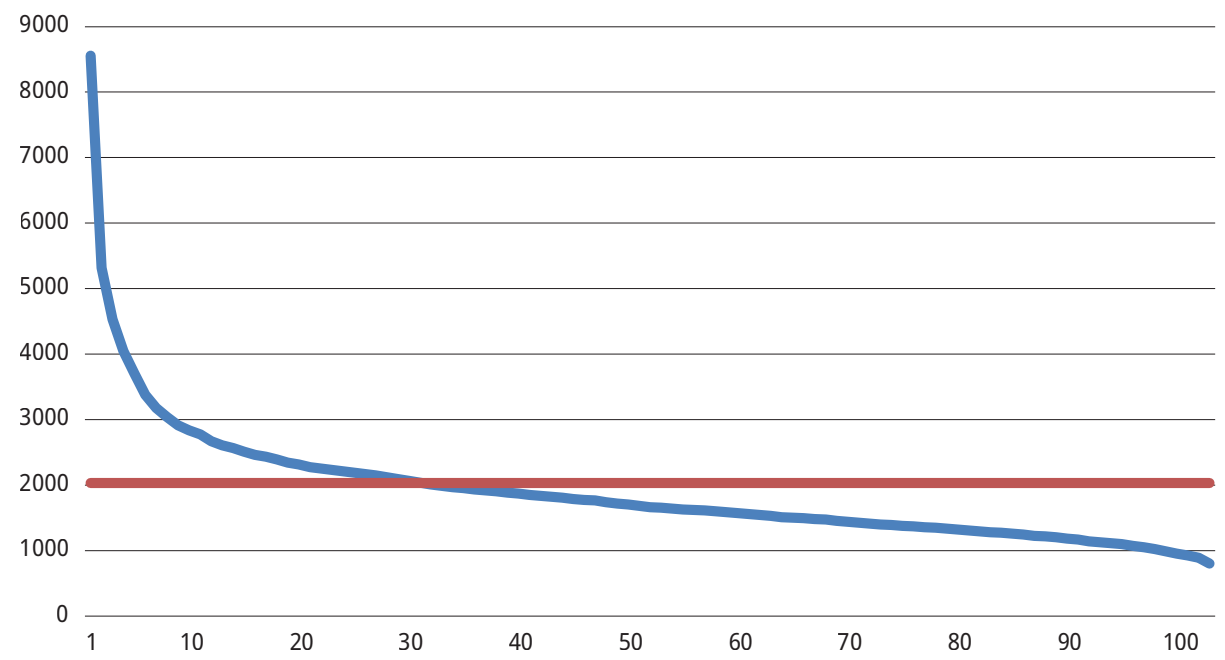

Źródło: obliczenia własne na podstawie: Ministerstwo Finansów, op. cit.

Istotną przeszkodą w skonstruowaniu dobrego systemu dochodów samorządowych jest bardzo duże rozdrobnienie JST i zróżnicowanie formalnie jednorodnych grup JST. Dobrze ilustrują to dane z tabeli 3. Widzimy, że najbardziej zróżnicowanymi wewnętrznie grupami JST są gminy wiejskie oraz miasta na prawach powiatu. O zróżnicowaniu miast na prawach powiatu decyduje m.in. zaliczenie do nich małych miast będących częścią dużych aglomeracji, takich jak Sopot, Mysłowice czy Świętochłowice. Dalsza analiza pokazuje, że nie ma istotnej zależności między liczbą mieszkańców miasta a poziomem dochodów na jednego mieszkańca.

Tabela 3. Zróżnicowanie wielkości jednostek samorządu terytorialnego w Polsce w 2019 r.

\begin{tabular}{|l|r|r|r|r|r|r|r|}
\hline \multirow{2}{*}{ Rodzaj jednostki } & Liczba & \multicolumn{3}{|c|}{ Ludność } & \multicolumn{3}{c|}{ Dochody na osobę (w zł) } \\
\cline { 5 - 9 } & $\begin{array}{l}\text { jedno- } \\
\text { stek }\end{array}$ & min. & max. & średnia & min. & max. & średnia \\
\hline MPP & 66 & 35827 & 1783321 & 190561 & 5153,0 & 10607,2 & 7465,5 \\
\hline Gminy miejskie (bez MPP) & 236 & 1303 & 73176 & 25004 & 3680,9 & 23041,2 & 5065,1 \\
\hline Gminy miejsko-wiejskie & 621 & 1654 & 84469 & 14374 & 3792,2 & 10648,6 & 5154,8 \\
\hline Gminy wiejskie & 1554 & 1511 & 33022 & 7067 & 3572,0 & 45832,0 & 5402,4 \\
\hline Powiaty & 314 & 20002 & 394541 & 82196 & 721,6 & 2309,9 & 1189,3 \\
\hline Województwa & 16 & 984345 & 5411446 & 2399155 & 367,7 & 749,8 & 488,6 \\
\hline
\end{tabular}

Źródło: obliczenia własne na podstawie: Ministerstwo Finansów, op. cit:; informacje o liczbie ludności zaczerpnięte z: Główny Urząd Statystyczny, Bank Danych Lokalnych, https://bdl.stat.gov.pl/BDL/ [dostęp: 28 kwietnia 2021 r.]. 
Oddzielnym problemem jest zbyt duża - naszym zdaniem - liczba JST. Efektem rozdrobnienia jednostek jest bowiem istnienie dużej liczby jednostek (zarówno gmin, jak i powiatów) o znikomym potencjale dochodowym, co w oczywisty sposób utrudnia wykonywanie przez nie zadań publicznych, a przy tym powoduje poważne komplikacje przy konstruowaniu efektywnego systemu wyrównawczego.

Wpływ potencjalnej konsolidacji JST na zróżnicowanie ich dochodów jest widoczny, gdy porównamy dwie mapy przedstawione na rysunku 1. Na mapie z lewej strony przedstawiono wielkość dochodów gmin w przeliczeniu na mieszkańca, a na mapie z prawej strony - dochody powiatu i wszystkich gmin w powiecie, przeliczone na jednego mieszkańca powiatu.

Rysunek 1. Rozkład dochodów gmin i powiatów na mieszkańca w 2019 r.
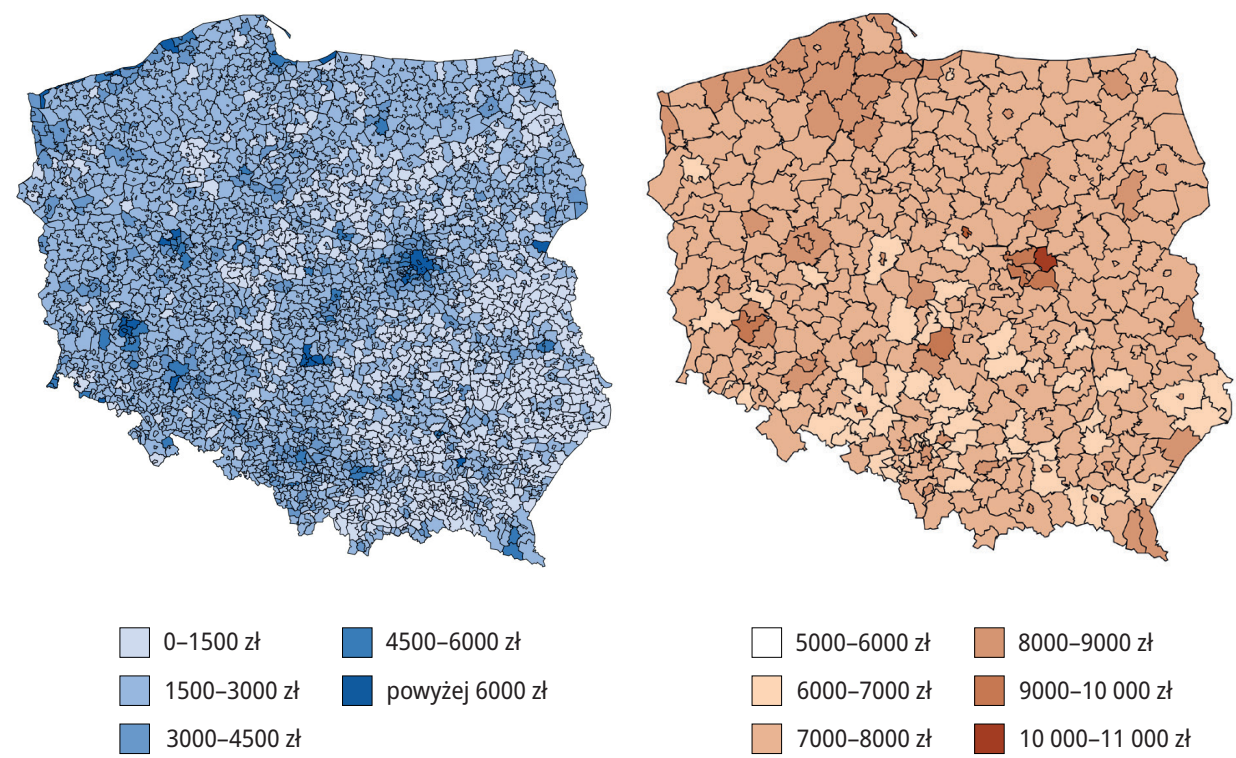

Źródło: obliczenia własne na podstawie: Ministerstwo Finansów, op. cit:; Główny Urząd Statystyczny, op. cit.

Tak jak zróżnicowane są dochody JST, tak zróżnicowane są również koszty - nawet w obrębie JST o identycznym statusie formalnym. Przykład takiego zróżnicowania pokazuje wykres 3, ilustrujący dane o rozkładzie wydatków na oświatę i wychowanie per capita w 2019 r. Długość słupków określa liczbę gmin, w których wydatki na ten cel mieszczą się w przedziałach opisanych na osi pionowej. Z wykresu tego możemy odczytać zarówno różnice pomiędzy wydatkami na oświatę w gminach wiejskich i miejsko-wiejskich, jak i zróżnicowanie jednostkowych wydatków w obrębie obu tych grup gmin.

Część różnic wydatkowych można wyjaśnić różnym (lepszym lub gorszym) sposobem zarządzania środkami publicznymi w poszczególnych gminach. Istotne są jednak również inne czynniki, takie jak istniejąca sieć budynków szkolnych (w wielu gminach możliwości inwestycyjne są 
Wykres 3. Wydatki gmin miejsko-wiejskich i wiejskich na oświatę i wychowanie w 2019 r. (w zł na mieszkańca)

\section{Gminy miejsko-wiejskie}

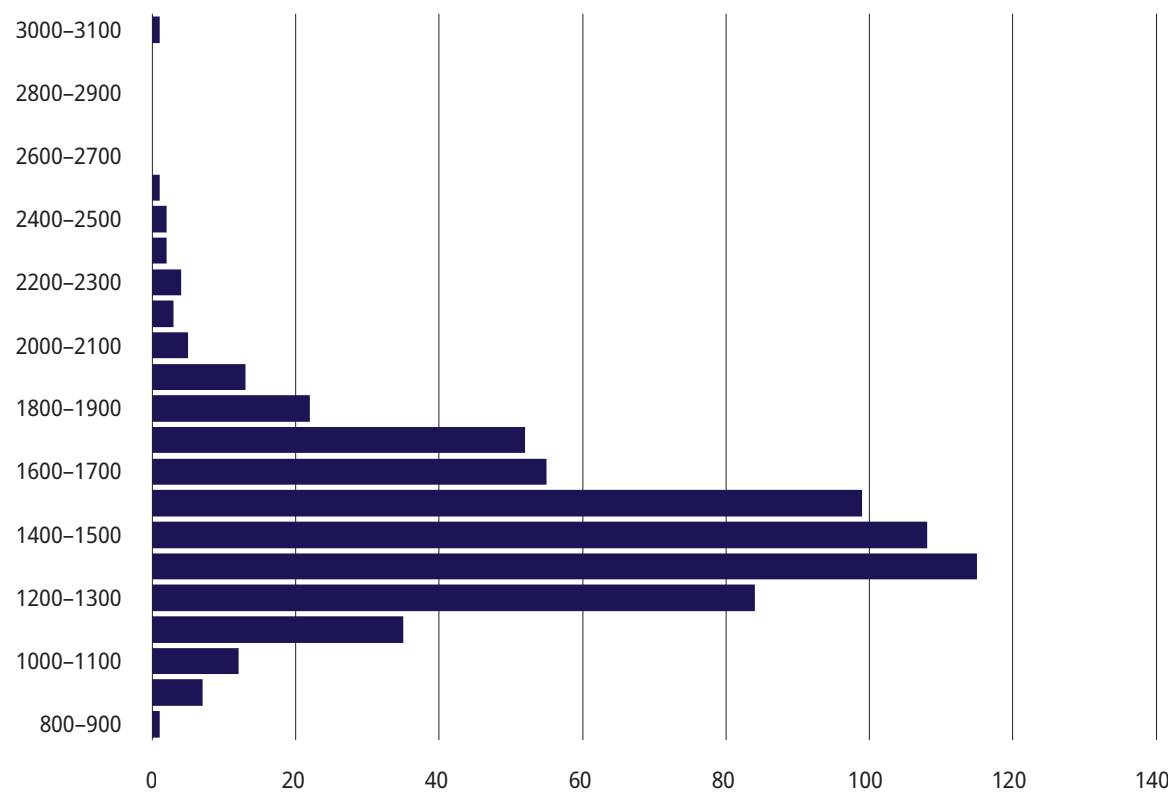

\section{Gminy wiejskie}

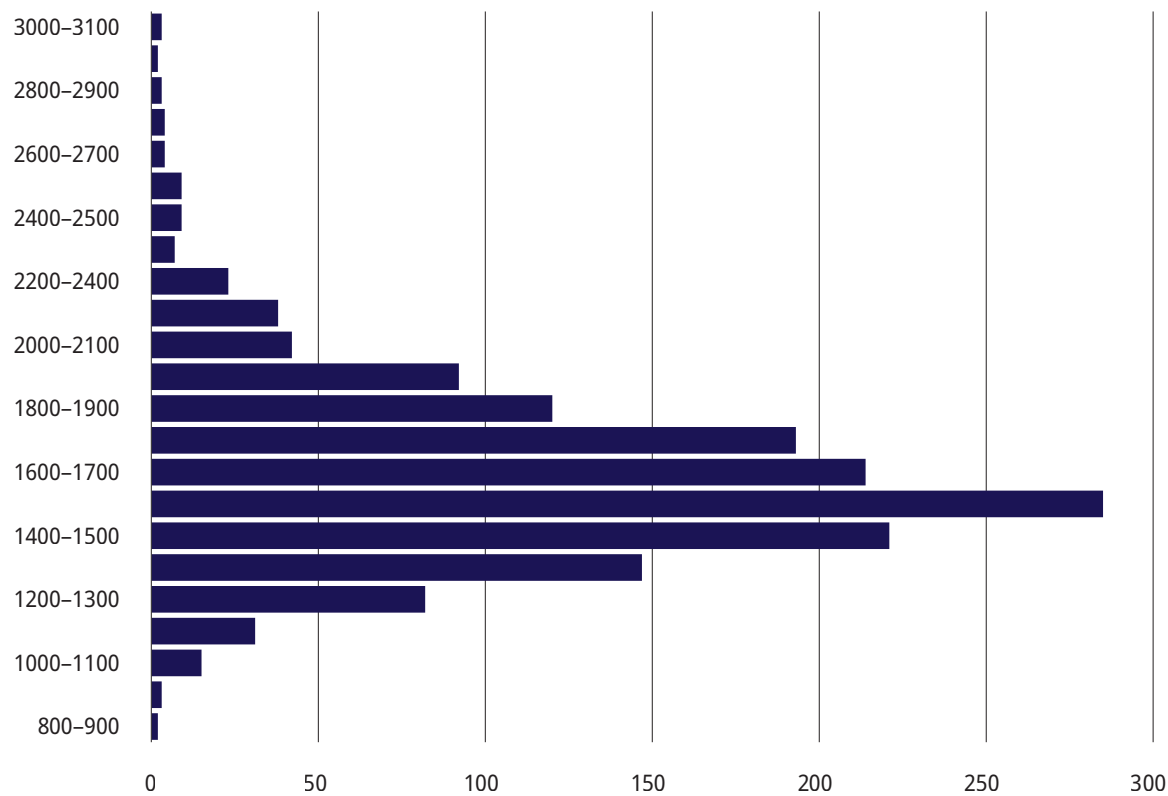


bardzo ograniczone), struktura demograficzna, odległość od większych ośrodków miejskich, a także rozmieszczenie ludności i ukształtowanie terenu gminy. Dobrze skonstruowany system dochodów samorządowych powinien uwzględniać wpływ przynajmniej niektórych z tych czynników na dochody i wydatki samorządowe. Ujmując to bardziej ogólnie: skala zróżnicowania dość jednorodnych co do rodzaju, a mimo to mocno zróżnicowanych wydatków na oświatę i wychowanie sugeruje potrzebę lepszego uwzględnienia przy konstrukcji systemu dochodów samorządowych obiektywnych różnic w poziomie niezbędnych wydatków na wykonywanie przez JST zadań publicznych. Elementy wiążące należne JST dochody z wartościami mierników obrazujących warunki, w jakich wykonywane są zadania publiczne, i wpływ tych warunków na koszty wykonywania zadań są wprawdzie obecne w obecnym systemie, wydaje się jednak, że powiązanie obiektywnie uzasadnionych kosztów wykonania zadań z dochodami należnymi JST powinno być mocniejsze.

\section{Wnioski}

1. W obecnym systemie prawnym dochody własne JST, łącznie z udziałami w podatkach dochodowych, pokrywają ok. 48,5\% wydatków JST, w tym:

- w gminach - 48,9\%, w tym w miastach na prawach powiatu - 56,8\%;

- w powiatach - 41,6\%;

- w województwach samorządowych - ok. 53,9\%.

2. Dochody własne gmin, w których przeważającym typem działalności gospodarczej jest rolnictwo (z wyłączeniem tzw. działów specjalnych), są wyraźnie niższe niż w pozostałych gminach. Jest to efekt specyficznego systemu opodatkowania rolnictwa, a także niedorozwoju infrastruktury społecznej i usług na tych terenach.

3. Możliwości zwiększenia udziału dochodów własnych JST przez przyznanie im wybranych rodzajów dochodów należnych obecnie Skarbowi Państwa są bardzo ograniczone, chociaż celowe byłoby rozważenie przekazania JST części składek na Fundusz Pracy i Państwowy Fundusz Rehabilitacji Osób Niepełnosprawnych (PFRON) oraz 100\% dochodów związanych z zadaniami wykonywanymi przez JST na zasadach zleconych z zakresu administracji rządowej. Możliwości zwiększenia dochodów własnych JST ogranicza również fakt, że w głębokiej nierównowadze znajduje się państwowy segment sektora finansów publicznych, podczas gdy zwiększenie dochodów własnych JST musiałoby oznaczać albo zmniejszenie dochodów sektora państwowego, albo stworzenie nowych tytułów dochodów publicznych i zwiększenie relacji dochodów publicznych do PKB - mało realne w obecnych warunkach.

4. Przesunięcie dochodów od sektora rządowego byłoby realne, gdyby udało się zracjonalizować wydatki tego sektora. Nie widać jednak dążenia do aktywnego podejmowania takiego zadania - świadczy o tym m.in. zaniechanie prowadzenia ocen planowania i gospodarowania środkami publicznymi przewidzianych w art. 176 ustawy o finansach publicznych ${ }^{10}$.

10 Ustawa z dnia 27 sierpnia 2009 r. o finansach publicznych (Dz.U. 2021, poz. 305). 
5. Stosunkowo prostym sposobem zwiększenia udziału dochodów własnych w finansowaniu wydatków JST byłoby zwiększenie udziałów we wpływach z podatków dochodowych (przede wszystkim udziałów we wpływach z PIT) kosztem ograniczenia dotacji budżetowych lub subwencji. Zmiana taka spowodowałaby jednak dalsze pogłębienie rozbieżności w poziomie dochodów pomiędzy gminami rolniczymi a resztą gmin.

6. Rolę systemu uzupełniania dochodów JST do poziomu gwarantującego możliwość wykonania zadań nałożonych na JST przypisano dotacjom i subwencji ogólnej z budżetu państwa oraz mającym o wiele mniejsze znaczenie dotacjom z różnego typu funduszy i agencji rządowych. Konstrukcja systemu dotacji i subwencji nie gwarantuje jednak jego efektywnego działania, gdyż:

- więcej niż połowę ogólnej kwoty subwencji ogólnej stanowi część oświatowa, rozdzielana z pominięciem kryterium dochodowego;

- algorytm podziału wyrównawczej części subwencji ogólnej polega głównie na wyrównywaniu poziomu dochodów i tylko w minimalnym stopniu uwzględnia niezbędne wydatki poszczególnych JST, chociaż dane statystyczne wykazują, że wydatki JST w kluczowych działach są mocno zróżnicowane nawet w obrębie grup podobnych jednostek i nie ma podstaw, by zakładać, że różnice te wynikają wyłącznie z lepszego lub gorszego zarządzania środkami publicznymi;

- funkcji wyrównawczej nie spełniają również dotacje przekazywane JST z budżetu państwa, ponieważ większość wypłacanych kwot stanowią dotacje finansujące zadania zlecone z zakresu administracji rządowej oraz dotacje finansowane środkami pochodzącymi z budżetu Unii Europejskiej - oznacza to, że dotacje nie są rozdzielane w sposób redukujący różnice w potencjale finansowym przeznaczonym na finansowanie zadań własnych.

7. Zastrzeżenia budzi też sposób dostosowywania dochodów do zmieniających się przepisów określających dochody budżetowe JST, a także koszty wykonywania zadań publicznych przypisanych JST. Dotyczy to w szczególności:

- niepełnego finansowania zadań zleconych;

- przypadków podejmowania decyzji zmniejszających dochody JST bez należytej rekompensaty;

- przypadków zwiększania zakresu zadań samorządowych lub standardu wykonywania tych zadań, powodującego wzrost kosztów ponoszonych przez JST, bez zapewnienia dodatkowych dochodów - używany wówczas argument, że dodatkowe koszty powinny być sfinansowane rosnącymi dochodami JST, nie jest zazwyczaj poparty szczegółowymi wyliczeniami pokazującymi, iż rosnące dochody JST są wystarczające do pokrycia dodatkowych kosztów; należy również zauważyć, że przyjęcie takiej linii rozumowania oznacza de facto postulat wyłączenia JST z podziału efektów wzrostu gospodarczego.

8. Analiza zmian dochodów i wydatków JST zachodzących po 1998 r. pozwala uznać, że wynikające z Konstytucji RP i Europejskiej Karty Samorządu Lokalnego ${ }^{11}$ gwarancje finansowe dla JST nie są w pełni realizowane. Z postanowieniami EKSL nie są również zgodne ograniczenia

11 Europejska Karta Samorządu Lokalnego, sporządzona w Strasburgu dnia 15 października 1985 r. (Dz.U. 1994, nr 124, poz. 607, z uwzględnieniem Dz.U. 2006, nr 154, poz. 1107; dalej: EKSL). 
dotyczące swobody gospodarowania środkami finansowymi pozostającymi w dyspozycji JST dotyczy to zwłaszcza sposobu rozliczania dotacji na zadania zlecone, istnienia „ukrytych funduszy celowych" wewnątrz budżetów JST, a także procedur zarządzania przez samorządy powiatów środkami Funduszu Pracy i PFRON. Szczególnym przypadkiem ograniczenia swobody dysponowania środkami finansowymi jest to, że JST odpowiadają za wypłaty wynagrodzeń nauczycieli, a wysokość tych wynagrodzeń jest regulowana odgórnie przepisami Karty Nauczyciela.

9. Konstrukcję efektywnego systemu finansów samorządowych utrudnia też nadmierne rozdrobnienie JST. Zasadne byłoby rozważenie istotnych zmian w podziale administracyjnym kraju, obejmujących w szczególności zmniejszenie liczby gmin. Kwestią dyskusyjną jest także zasadność dalszego funkcjonowania powiatów.

\section{Możliwości korekty - główne postulaty}

Uchwalona w 2003 r. ustawa o dochodach jednostek samorządu terytorialnego była wielokrotnie nowelizowana, lecz zasadnicza konstrukcja systemu finansów samorządowych nie uległa mimo to istotnym zmianom. Opisane powyżej niedoskonałości tego systemu wskazują na potrzebę ponownego rozważenia zasad finansowania zadań samorządowych. W naszym przekonaniu nowa ustawa o finansowaniu jednostek samorządu terytorialnego powinna w szczególności doprowadzić do:

- zasadniczej zmiany konstrukcji subwencji ogólnej;

- zniesienia większości ograniczeń w swobodnym dysponowaniu środkami finansowymi JST.

Za celowe uważamy również powiązanie prac nad nowym systemem finansów samorządowych z weryfikacją zakresu zadań publicznych wykonywanych przez JST, a także z rozważeniem zmian w podziale administracyjnym kraju.

\section{Zakres i finansowanie zadań samorządu terytorialnego}

Jak zaznaczyliśmy na wstępie, kwestia zakresu zadań publicznych przypisanych jednostkom samorządu terytorialnego powinna być rozstrzygnięta przed rozpoczęciem prac nad systemem finansowym. Wydaje się to oczywiste, gdyż podstawowym kryterium, którego spełnienia wymaga się od poprawnie skonstruowanego systemu finansów samorządowych, jest zapewnienie wystarczających środków na finansowanie wszystkich zadań JST. Skoro jednak obowiązujący obecnie zakres zadań samorządowych budzi dość istotne wątpliwości - i to zarówno z punktu widzenia jego zgodności z konstytucyjną zasadą pomocniczości, jak i z perspektywy zagwarantowania faktycznej samodzielności finansowej JST - to celowe wydaje się, by reformę finansów samorządowych połączyć z korektą zakresu zadań.

Proponowane przez nas zmiany dotyczą w szczególności trzech kwestii:

- ograniczenia zakresu zadań zleconych jednostkom samorządu terytorialnego na mocy ustaw;

- przekazania gminom środków Narodowego Funduszu Zdrowia na kontraktowanie usług z zakresu podstawowej opieki zdrowotnej; 
- przejęcia przez Skarb Państwa zadania polegającego na finansowaniu wynagrodzeń nauczycieli w szkołach podstawowych i ponadpodstawowych.

O celowości przekazania gminom środków na finansowanie usług podstawowej opieki zdrowotnej decyduje przede wszystkim ewidentnie lokalny charakter zadania. Za takim rozwiązaniem przemawia również fakt, że do zadań własnych gmin należy - zgodnie z art. 7 ust. 1 pkt 1 ustawy z dnia 27 sierpnia 2004 r. o świadczeniach opieki zdrowotnej finansowanych ze środków publicznych $^{12}$ - opracowywanie i realizacja oraz ocena efektów programów polityki zdrowotnej wynikających z rozpoznanych potrzeb zdrowotnych i stanu zdrowia mieszkańców gminy.

Postulat przejęcia przez Skarb Państwa finansowania wynagrodzeń nauczycieli wynika z faktu, że wydatki gmin na ten cel są przede wszystkim kształtowane przepisami ustawowymi, z jednoczesnym przeniesieniem na gminy „ryzyka legislacyjnego”, polegającego na niedostosowaniu wielkości dochodów JST i skali ich zmian do regulacji zwiększających obligatoryjne wydatki JST. Tego typu rozwiązanie (JST odpowiadają za organizację szkół, utrzymanie budynków i wyposażenia oraz za wynagrodzenia personelu pomocniczego) stosowane są w wielu państwach europejskich.

\section{Zakres i finansowanie zadań zleconych}

Problemów związanych z finansowaniem zadań ustawowo zleconych JST nie da się - naszym zdaniem - rozwiązać bez zasadniczych zmian samej konstrukcji zadań zleconych. Zmiany powinny przy tym obejmować zarówno zakres zadań publicznych finansowanych w tej formie, jak i sposób ich finansowania, przy czym podstawą do określenia nowego kształtu systemu zadań zleconych powinny być następujące założenia:

- zakres zadań zleconych wykonywanych w sposób ciągły należy radykalnie ograniczyć;

- ograniczenie zakresu zadań zleconych powinno polegać albo na przejęciu przez administrację rządową wykonywania zadań zleconych obecnie JST (tu należy rozważyć zwłaszcza zasadność zlecania samorządom powiatów finansowania państwowej straży pożarnej, a także wykonywania przez starostów zadań związanych z zarządzaniem nieruchomościami Skarbu Państwa), albo na nadaniu obecnym zadaniom zleconym statusu obligatoryjnych zadań własnych;

- formę zadań zleconych wykonywanych w sposób ciągły należy pozostawić tylko dla tych zadań, których przejęcie przez administrację rządową powodowałoby istotne niedogodności dla obywateli - w praktyce oznaczałoby utrzymanie formy zadania zleconego jedynie dla wypłat świadczeń o charakterze pomocy społecznej i wspierania rodziny oraz dla dopłat do zakupów paliwa dla rolników.

Wprowadzenie tych zmian wymagałoby zastąpienia dotacji na zadania zlecone, przekształcane w obligatoryjne zadania własne, innymi dochodami - np. przez zmodyfikowanie reguł wyznaczania subwencji ogólnej. 


\section{Konstrukcja subwencji ogólnej}

Analiza obowiązującego obecnie algorytmu obliczania należnej JST subwencji ogólnej wykazała, że ma on dwie podstawowe wady:

- przez włączenie do subwencji ogólnej transferów służących finansowaniu przez wszystkie JST zadań edukacyjnych uległa zatarciu wyrównawcza rola subwencji ogólnej;

- przy wyliczaniu należnej JST subwencji uwzględnia się tylko potencjał podatkowy tej jednostki (który nie jest identyczny z dochodami), pomija się natomiast istotnie wpływające na zdolność JST do wykonywania zadań publicznych zróżnicowanie wydatków niezbędnych w konkretnych warunkach danej jednostki - do właściwego wykonania tych zadań.

Przedstawiona poniżej nowa formuła obliczania subwencji ogólnej została po raz pierwszy zaproponowana - w nieco innej wersji - w 2008 r. ${ }^{13}$ Ideę proponowanej koncepcji przedstawimy poniżej na przykładzie subwencji dla gmin. Zakładamy, że subwencja dla powiatów i województw byłaby konstruowana na analogicznych zasadach, lecz z uwzględnieniem specyfiki każdego z rodzajów JST. Nowa subwencja ogólna ma się składać z dwóch części, oznaczanych dalej jako „subwencja A" i „subwencja B”. Obie mają charakter subwencji wyrównawczych, przy czym zasadniczą rolę odgrywa subwencja A, a subwencja B ma stanowić jej uzupełnienie dla niewielkiej liczby gmin. Odchodzimy więc od założenia, że subwencję ogólną powinny otrzymywać wszystkie gminy.

Należna gminom subwencja A ma być obliczana według wzoru:

$$
S_{j}^{A}=\left\{\begin{array}{ll}
a \cdot\left(Z_{j}-P_{j}\right) & \text { dla } Z_{j}>P_{j} \\
0 & \text { dla } Z_{j} \leq P_{j}^{\prime}
\end{array}, j=1,2, \ldots, 2477\right.
$$

gdzie $S_{j}^{A}$ oznacza należną gminie subwencję $A, Z_{j}$ jest standaryzowanym zapotrzebowaniem gminy na środki finansowe, $P_{j}$ oznacza potencjał dochodowy tej gminy, a parametr a określa stopień wyrównywania luki między potencjałem dochodowym a zapotrzebowaniem na środki finansowe.

Dla konkretnej JST wielkość potencjału dochodowego $(P)$ byłaby obliczana podobnie jak obecnie - jako suma wybranych, najważniejszych dochodów własnych (wraz z udziałami w podatkach dochodowych), obliczona z danych za ostatni rok, dla którego dostępne są dane sprawozdawcze.

Istotną modyfikacją sposobu wyznaczania potencjału dochodowego (nazywanego w obecnym systemie podstawowymi dochodami podatkowymi) byłoby przyjęcie, że skutki udzielonych ulg, zwolnień i stosowania niższych od maksymalnych stawek podatków lokalnych byłyby wliczane do potencjału dochodowego tylko w części wynikającej z wyższej niż przeciętna krajowa relacji kwoty ulg, zwolnień i skutków stosowania niższych stawek podatkowych do zrealizowanych dochodów własnych danej jednostki.

13 J. Mackiewicz-Łyziak, E. Malinowska-Misiąg, W. Misiąg, M. Tomalak, Wyrównywanie dochodów jednostek samorzq̨du terytorialnego. Możliwości wykorzystania w Polsce doświadczeń niemieckich krajów zwiq̨zkowych, Instytut Badań nad Gospodarką Rynkową, Warszawa 2008, s. 166-169. 
Do wyliczenia zapotrzebowania na środki finansowe (Z) zostałaby wykorzystana formuła:

$Z_{j}=\Phi_{1}\left(V_{j}, X_{j}\right)+G_{j} \cdot \Phi_{2}\left(V_{j}, Y_{j}\right), j=1,2, \ldots, 2477$

gdzie:

$V_{j}$ - przeliczeniowa liczba mieszkańców;

$G_{j}$ - zmienna wskaźnikowa, przyjmująca wartość 1 dla MPP i 0 dla pozostałych gmin;

$\Phi_{1}$ - funkcja określająca na podstawie kilku wskaźników tworzących wektor $X_{i}$ przypadające na jednego mieszkańca standardowe koszty wykonania zadań gminy;

$\Phi_{2}$ - funkcja określająca na podstawie kilku wskaźników tworzących wektor $Y_{i}$ przypadające na jednego mieszkańca standardowe koszty wykonania zadań powiatu.

Przy ustalaniu szczegółowej specyfikacji zmiennych tworzących wektory $X$ i $Y$ istotne jest, by dla wybranych i możliwie nielicznych wskaźników dostępne były rzetelne dane o ich wartościach, a wskaźniki te były ściśle związane z kosztami wykonywania najważniejszych zadań JST.

Przeliczeniowa liczba mieszkańców powinna być wyznaczana w sposób zapewniający preferencje dla gmin najmniejszych (ze względu na wysoki udział kosztów stałych) i dla gmin największych, w których koszty wykonywania zadań publicznych rosną na ogół szybciej od liczby ludności.

Subwencja B ma charakter uzupełniający i służy zapewnieniu każdej gminie pewnego minimalnego poziomu dochodów. Subwencja B byłaby obliczana zgodnie ze wzorem:

$S_{j}^{B}=\left\{\begin{array}{ll}\left.\left(\beta-\frac{D_{j}}{D^{*}}\right) \cdot D^{*} \cdot L_{j}\right) & \text { dla } D_{j}<\beta \cdot D^{*} \\ 0 & \text { dla } D_{j} \geq \beta \cdot D^{*}\end{array}, j=1,2, \ldots, 2477\right.$

gdzie $D_{j}$ oznacza dochody na jednego mieszkańca (bez subwencji B) w j-tej gminie, $D^{*}$ jest średnią wartością dochodów na jednego mieszkańca we wszystkich gminach, a parametr $\beta$ określa procent średnich dochodów wszystkich gmin, który chcemy zagwarantować każdej gminie. Wartość parametru $\beta$ powinna mieścić się w przedziale 0,6-0,75, lecz dokładne określenie wartości tego i kilku innych parametrów wymaga przeprowadzenia wielowariantowych obliczeń symulacyjnych.

Koncepcja nowej subwencji ogólnej nie przewiduje obciążenia jednostek o najwyższych dochodach obowiązkiem dokonywania wpłat do budżetu państwa.

\section{Dochody celowe}

Dla sprawnego zarządzania finansami samorządowymi istotna jest nie tylko kwota otrzymywanych dochodów, lecz także możliwość elastycznego kształtowania struktury wydatków bez konieczności uwzględniania ograniczeń wynikających ze struktury dochodów. Nowy system finansów samorządowych powinien więc być budowany z założeniem usuwania obligatoryjnych powiązań rodzajów dochodów z rodzajami wydatków, które mogą być z tych dochodów 
finansowane. Największe znaczenie będą tu miały zmiany dotyczące zadań zleconych z zakresu administracji rządowej. Celowe byłoby jednak wprowadzenie dalszych korekt obowiązującego obecnie systemu, w tym w szczególności włączenie do budżetów powiatów środków Funduszu Pracy i PFRON oraz uchylenie przepisów wiążących wybrane rodzaje dochodów własnych z określonymi rodzajami wydatków.

\section{Udziały w podatkach dochodowych i lokalny podatek obrotowy}

Oczywista wydaje się konieczność utrzymania udziałów we wpływach z podatku dochodowego od osób fizycznych jako jednego z podstawowych źródeł finansowania zadań samorządowych. Wysokość udziałów gmin, powiatów i województw we wpływach z PIT musiałaby przy tym zostać ponownie skalkulowana stosownie do zmian zakresu zadań i nowej konstrukcji subwencji ogólnej.

Więcej wątpliwości budzi natomiast finansowanie JST udziałami w podatku dochodowym od osób prawnych. Większość wpływów z CIT pochodzi od podmiotów ze sektora finansowego i JST mają mocno ograniczony wpływ na ich wielkość. Przeciwko udziałom w CIT przemawia również duża niestabilność dochodów z tego tytułu i ich podatność na działania tzw. agresywnej optymalizacji podatkowej ${ }^{14}$. Część problemów z udziałami w CIT mogłoby rozwiązać obniżenie stawki CIT i zastąpienie części wpływów z udziałów w tym podatku dochodami z lokalnego podatku pobieranego od obrotu firm handlowych i usługowych. Byłoby to szczególnie istotne dla gmin, które z racji pełnionych funkcji obsługują liczbę osób przewyższającą znacznie liczbę mieszkańców tych gmin.

\section{Bibliografia}

Brzozowska K., Kogut-Jaworska M., Władztwo podatkowe w ocenie samodzielności dochodowej gmin w Polsce, „Annales Universitatis Mariae Curie-Skłodowska. Sectio H. Oeconomia” 2016, t. 50, nr 1, https://doi. org/10.17951/h.2016.50.1.327.

Dylewski M., The Financing of Public Tasks Delegated to Local Governments - An Unresolved Systemic Problem, „Zeszyty Naukowe Wyższej Szkoły Bankowej w Poznaniu” 2016, t. 70, nr 5.

Glumińska-Pawlic J., Samodzielność finansowa jednostek samorzq̨du terytorialnego w Polsce. Studium finansowoprawne, Wydawnictwo Uniwersytetu Śląskiego, Katowice 2003.

Kańduła S., Mechanizmy wyrównywania fiskalnego. Studium empiryczne gmin w Polsce w latach 2004-2014, Wydawnictwo Uniwersytetu Ekonomicznego w Poznaniu, Poznań 2017.

Mackiewicz-ŁyziakJ., Malinowska-Misiąg E., Misiąg W., Tomalak M., Wyrównywanie dochodów jednostek samorzq̨du terytorialnego. Możliwości wykorzystania w Polsce doświadczeń niemieckich krajów zwiq̨zkowych, Instytut Badań nad Gospodarką Rynkową, Warszawa 2008.

Malinowska-Misiąg E., Finansowanie zadań zlecanych jednostkom samorządu terytorialnego, "Studia BAS" 2017, nr 4(52) [Finansowanie zadań publicznych w Polsce, red. P. Russel].

14 Najwyższa Izba Kontroli, Informacja o wynikach kontroli. Agresywna optymalizacja podatkowa w zakresie CIT, Warszawa 2019. 
Najwyższa Izba Kontroli, Informacja o wynikach kontroli. Agresywna optymalizacja podatkowa w zakresie CIT, Warszawa 2019.

Patrzałek L., Subwencja ogólna jako instrument korekcyjno-wyrównawczy w systemie finansów samorzqdu terytorialnego, „Prace Naukowe Uniwersytetu Ekonomicznego we Wrocławiu” 2015, nr 404 [Finanse samorzadu terytorialnego, red. L. Patrzałek, H. Kociemska], https://doi.org/10.15611/pn.2015.404.16.

Poniatowicz M., Determinanty autonomii dochodowej samorzadu terytorialnego w Polsce, „Prace Naukowe Uniwersytetu Ekonomicznego we Wrocławiu" 2015, nr 404 [Finanse samorzq̨du terytorialnego, red. L. Patrzałek, H. Kociemska], https://doi.org/10.15611/pn.2015.404.17.

Rada Ministrów, Sprawozdanie z wykonania budżetu państwa za okres od 1 stycznia do 31 grudnia 2019 r. Informacja o wykonaniu budżetów jednostek samorządu terytorialnego, Warszawa 2020.

Sekuła A., System subwencjonowania jednostek samorzqdu terytorialnego w Polsce: dysfunkcje i pożq̨dane kierunki racjonalizacji, Wydawnictwo Politechniki Gdańskiej, Gdańsk 2016.

Surówka K., Samodzielność finansowa samorzadu terytorialnego w Polsce, Polskie Wydawnictwo Ekonomiczne, Warszawa 2013.

Szołno-Koguc J., Subwencja ogólna jako instrument wsparcia transferowego samorządu gminnego, „Prace Naukowe Uniwersytetu Ekonomicznego we Wrocławiu" 2017, nr 485 [Relacje fiskalne państwo - samorzad terytorialny, red. L. Patrzałek, H. Kociemska], http://dx.doi.org/10.15611/pn.2017.485.37.

Wójtowicz K., Udziały samorządów w podatkach państwowych - własne czy obce źródło dochodów JST? Dylematy teorii a praktyka budżetowa wybranych państw , „Prace Naukowe Uniwersytetu Ekonomicznego we Wrocławiu” 2013, nr 306.

Wyszkowska D., Samodzielność finansowa jako determinanta potencjału inwestycyjnego jednostek samorzadu terytorialnego. Studium empiryczne gmin w Polsce, Wydawnictwo Uniwersytetu w Białymstoku, Białystok 2018.

\section{Akty prawne}

Europejska Karta Samorządu Lokalnego, sporządzona w Strasburgu dnia 15 października 1985 r. (Dz.U. 1994, nr 124, poz. 607, z uwzględnieniem Dz.U. 2006, nr 154, poz. 1107).

Konstytucja Rzeczypospolitej Polskiej z dnia 2 kwietnia 1997 r. (Dz.U. nr 78, poz. 483, ze zm.).

Ustawa z dnia 20 grudnia 1996 r. o gospodarce komunalnej (Dz.U. 2021, poz. 679).

Ustawa z dnia 13 listopada 2003 r. o dochodach jednostek samorządu terytorialnego (Dz.U. 2021, poz. 38).

Ustawa z dnia 27 sierpnia 2004 r. o świadczeniach opieki zdrowotnej finansowanych ze środków publicznych (Dz.U. 2020, poz. 1398, ze zm.).

Ustawa z dnia 27 sierpnia 2009 r. o finansach publicznych (Dz.U. 2021, poz. 305).

\section{Źródła internetowe}

Główny Urząd Statystyczny, Bank Danych Lokalnych, https://bdl.stat.gov.pl/BDL/.

Ministerstwo Finansów, Bazy danych po IV kwartałach 2019 r. - Dochody po IV kwartałach 2019 r., https://www. gov.pl/web/finanse/bazy-danych2. 